\title{
MENGUAK KESENJANGAN ANTARA PASAR MODERN DAN PASAR TRADISIONAL
}

\author{
Khusnul Khotimah, Dadang Hartanto, Nuruh Alipah \\ Universitas Trunojoyo Madura
}

\begin{abstract}
This study is entitled "Perception of the Community Against Modern Markets" This study presents two formulations of the problem, namely whether the influence of modern markets on the social life of the community and how the public perception of the modern market in Kamal, Bangkalan Regency. Based on the formulation of the problem, this study has a purpose to see people's perception of the existence of a modern market in Kamal, Bangkalan Regency. To find out the influence of the modern market on people's social life in Kamal, Bangkalan Regency. To know the development of capitalism in Indonesia by connecting capitalism and the development of modern markets. This type of research is qualitative descriptive, using several informants to conduct interviews and observations. The source of the data used is the primary source, namely information that comes from direct observation to the research location by means of observation and interviews. While secondary sources are data obtained from documentation or library studies to complete primary data. Data collection is carried out through field research through observation, interviews, and documentation.
\end{abstract}

Keywords: Perception,Modern Market.

\section{PENDAHULUAN}

\section{Latar Belakang}

Dunia saat ini dikuasai oleh kapitalisme. Ini merupakan produk sejarah perkembangan masyarakat, bukan kehendak manusia, perkembangan kapitalisme merupakan suatu keharusan sejarah. Kapitalisme merupakan anak kandung feodalisme. Kapitalisme menguasai kehidupan sosial, politik dan budaya. Secara tidak langsung, pasar modern juga memperlihatkan bahwa kapitalisme mulai menjajah ke-Indonesia, padahal secara tekstual Indonesia menganut sistem perekonomian Pancasila yang berasaskan kekeluargaan (koperasi). Sistem kapitalisme sangat menguntungkan bagi pemilik modal. Kapitalisme memberikan keleluasaan para pemilik modal untuk menjalankan perekonomian yang bertujuan mencari keuntungan sebesar-besarnya, maka pemilik modal besar akan memiliki kesempatan seluas-luasnya dalam mengembangkan sayap perekonomian, tetapi bagi pedagang tradisional yang memiliki modal kecil sulit bersaing dengan pasar modern akan merugi hingga akhirnya bangkrut atau gulung tikar. 
Kebebasan dalam melakukan $\mathrm{k}$ egiatan ekonomi yang tidak ada batasnya dapat merugikan golongan yang lemah dan kaum minoritas. Persaingan yang sangat bebas menyebabkan golongan yang kuat kedudukannya bertambah kuat lagi. Persebaran pasar modern pada satu sisi memiliki dampak yang positif, hal ini membuktikan adanya pertumbuhan ekonomi yang cukup tinggi dan menciptakan investasi, namun disisi lain hal ini dapat menyebabkan kelesuan para pedagang kecil seperti pedagang kaki lima, bahkan mematikanv usaha mereka. Kehadiran pasar modern tersebut telah memunculkan iklim persaingan yang tidak sehat yang merugikan pedagang kios kecil. Tidak menutup kemungkinan, kondisi yang timpang tersebut juga berpotensi munumbuhkan benih-benih kecemburuan sosial diantara para pelaku perdagangan. Membuat pedagang kios kecil semakin terpuruk, bahkan mati karena tergerus keberadaan pasar modern yang menawarkan kenyamanan berbelanja, kemudahan pembayaran, kualitas produk yang lebih baik dan nilai plus lainnya bila dibandingkan dengan apa yang dapat ditawarkan oleh pedagang pasar tradisional.

Masyarakat desa yang awalnya memiliki ciri-ciri ikatan solidaritas yang kuat, masyarakat yang homogen, masyarakat yang tertutup akan penemuan baru, dinamis, dan punya sifat yang unik pedalaman dimana sifat ini sebagai akibat dari kurangnya kontak dengan dunia luar, mereka sangat toleran dengan nilai-nilai yang dimilikinya, dan sangat intoleran terhadap nilai-nilai yang dimiliki kelompok lain. Namun terlihat sekarang sudah mengalami perubahan sosial dimana masyarakat desa mulai terbuka terhadap hal-hal baru. Contoh yang dapat kita lihat di pasar modern yang awalnya masyarakat hanya berbelanja di pasar tradisional namun sekarang sudah beralih ke pasar modern.

Penulis dalam penelitian ini akan menfokuskan pada pasar modern dan masyarakat di Kamal Kabupaten Bangkalan. Untuk mengetahui bagaimana pengaruh Pasar modern terhadap kehidupan sosial masyarakat dan bagaimana persepsi masyarakat terhadap pasar modern di Kamal Kabupaten Bangkalan.

\section{Rumusan Masalah}

1. Bagaimana gambaran lokasi penelitian?

2. Apakah pengaruh Pasar modern terhadap kehidupan sosial masyarakat di Kecamatan Kamal Kabupaten Bangkalan? 
3. Bagaimana persepsi masyarakat terhadap Pasar modern di Kecamatan Kamal Kabupaten Bangkalan?

\section{TINJAUAN PUSTAKA}

Pengertian persepsi

Persepsi adalah sebuah proses saat individu mengatur dan menginterpretasikan kesan-kesan sensoris mereka guna memberikan arti bagi lingkungan mereka. Perilaku individu seringkali didasarkan pada persepsi mereka tentang kenyataan, bukan pada kenyataan itu sendiri. Persepsi merupakan suatu proses yang didahului oleh pengindraan. Pengindran merupakan suatu proses diterimahnya stimulus oleh individu melalui alat penerima yaitu indra. Namun proses tersebut tidak berhenti disitu saja, pada umumnya stimulus tersebut diteruskan oleh syaraf ke otak sebagai pusat susunan syaraf, dan proses selanjutnya merupakan proses persepsi. Karena itu proses persepsi tidak dapat terlepas dari proses penginderaan, dan proses penginderaan merupakan proses yang mendahului terjadinya persepsi. Proses penginderaan terjadi setiap saat yaitu pada individu menerima stimulus yang mengenai dirinya melalui alat indra. Alat indra merupakan penghubung antara individu dengan dunia luarnya.

Stimulus yang mengenai individu itu kemudian diorganisasikan, diinterpretasikan, sehingga individu menyadari tentang apa yang diinderakannya itu. Proses inilah yang dimaksud dengan persepsi. Jadi stimulus diterima oleh alat indera kemudian melalui proses persepsi sesuatu yang dinderakan tersebut menjadi sesuatu yang berarti setelah diorganisasikan dan interpretasikan. Persepsi merupakan proses yang intergrated dari individu terhadap stimulus yang diterimahnya. Dengan demikian dapat dikemukakan bahwa persepsi merupakan proses pengorganisasian, penginterpretasian terhadap stimulus yang diterimah oleh orgasnisme atau individu sehingga merupakan sesuatu yang berarti dan merupakan aktivitas yang intergrated dalam diri individu. Karena merupakan aktivitas yang intergrated, maka seluruh pribadi, seluruh apa yang ada dalam diri individu ikut aktif berperan dalam persepsi itu.

Persepsi dapat membuat individu dapat menyadari, dapat mengerti tentang keadaan lingkungannya yang ada disekitarnya, dan juga tentang keadaan diri individu yang bersangkutan. Dengan demikian dapat dikemukakan bahwa dalam persepi stimulus dapat datang dari luar dari individu, tetapi dapat juga datang dari dalam diri individu yang 
bersangkutan. Bila yang dipersepsikan dirinya sendiri sebagai objek persepsi, inilah yang disebut persepsi diri (self perseption) karena dalam persepsi itu merupakan aktivitas yang intergrated, maka seluruh apa yang ada dalam diri individu seperti perasaan, pengalaman, kemampuan berfikir, kerangka acuan, dan aspek-aspek lain yang ada dalam individu akan ikut berperan dalam persepsi tersebut. Berdasarkan atas hal tersebut dapat dikemukakan bahwa dalam persepsi tersebut. Berdasarkan atas hal tersebut dapat dikemukakan bahwa dalam persepsi itu sekalipun stimulus sama, tetapi karena pengalaman tidak sama, kemampuan berfikir tidak sama, kerangka acuan tidak sama, adanya acuan tidak sama, adanya kemungkinan hasil persepsi antara individu satu dengan individu yang lain tidak sama. Keadaan tersebut memberikan memberikan gambaran bahwa persepsi itu memang bersifat individual.Persepsi merupakan kesan yang pertama untuk mencapai suatu keberhasilan.

Persepsi seseorang dalam menangkap informasi dan peristiwa-peristiwa menurut Muhyadi persepsi dipengaruhi oleh tiga faktor, yaitu:

a. Orang yang membentuk persepsi itu sendiri, khususnya kondisi intern (kebutuhan, kelelahan, sikap, minat, motivasi, harapan, pengalaman masa lalu dan kepribadian).

b. Stimulus yang berupa objek maupun peristiwa tertentu (benda, orang, proses dan lain-lain).

c. Stimulus dimana pembentukan persepsi itu terjadi baik tempat, waktu, suasana (sedih, gembira dan lain-lain).

Persepsi merupakan konsep yang sangat penting dalam psikologi, kalau bukan dikatakan yang paling penting. Melalui persepsilah manusia memandang dunianya Apakah dunia terlihat berwarna cerah, pucat, atau hitam, semuanya adalah persepsi manusia yang bersangkutan. Persepsi harus dibedakan dengan sensasi .Yang terakhir ini merupakan fungsi fisiologis, dan lebih banyak tergantung pada kematangan dan berfungsinya organorgan sensoris. Sensasi meliputi fungsi visual, audio, penciuman dan pengecapan, serta perabaan, keseimbangan dan kendali gerak. Kesemuanya inilah yang sering disebut indera. Jadi dapat dikatakan bahwa sensasi adalah proses manusia dalam menerima informasi sensoris (energi fisik dari lingkungan) melalui penginderaan dan menerjemahkan informasi tersebut menjadi sinyal-sinyal neural yang bermakna. Misalnya, ketika seseorang melihat (menggunakan indera visual, yaitu mata) sebuah benda berwarna merah, maka ada 
gelombang cahaya dari benda itu yang ditangkap oleh organ mata, lalu diproses dan ditransformasikan menjadi sinyal-sinyal di otak, yang kemudian diinterpretasikan sebagai "warna merah". Berbeda dengan sensasi, persepsi merupakan sebuah proses yang aktif dari manusia dalam memilah, mengelompokkan, serta memberikan makna pada informasi yang diterimanya.

Otak manusia juga menggunakan metode kerja dari kelima jalur informasi tersebut dalam memproses dan mengambil kembali berbagai informasi yang telah dipelajari. Individu umumnya mampu menyesualisasikan, berbicara dengan dirinya sendiri, merasakan (secara fisik atau emosional), membedakan berbagai rasa, membedakan berbagai aroma dan masih banyak lagi. Setiap individu memiliki preferensi yang berbeda saat memproses informasi dan menindak lanjuti hasil pemikirannya dalam bentuk tindakan atau eksperesi.

\section{Perkembangan masyarakat}

Pengembangan masyarakat (community development) terdiri dari dua konsep, yaitu pengembangan dan masyarakat. Secara singkat, pengembangan merupakan usaha bersama dan terencana untuk meningkatkan kualitas kehidupan manusia. Telah disebutkan bahwa konsep dari komunitas adalah sekelompok orang dengan identitas bersama. Oleh karena itu, pengembangan masyarakat bergantung pada interaksi antara manusia dan aksi bersama dari pada kegiatan individu apa yang beberapa ahli sosiologi menyebutnya dengan lembaga kolektif. Bidang-bidang pembangunan biasanya meliputi beberapa sektor, yaitu ekonomi, pendidikan, kesehatan dan sosial budaya. Masyarakat dapat diartikan dalam dua konsep yaitu:

1. Masyarakat sebagai sebuah tempat bersama, yakni sebuah wilayah geografi yang sama. Sebagai contoh, sebuah rukun tetangga, perumahan di daerah perkotaan atau sebuah kampung di wilayah pedesaan.

2. Masyarakat sebagai kepentingan bersama, yakni kesamaan kepentingan berdasarkan kebudayaan dan identitas. Sebagai contoh, kepentingan bersama pada masyarakat etnis minoritas atau kepentingan bersama berdasarkan identifikasi kebutuhan tertentu.

3. Pengembangan sendiri menurut United Nation adalah Pengembangan adalah suatu proses yang didesain untuk menciptakan kondisi ekonomi dan kemajuan sosial 
untuk komunitas yang berhubungan dengan partisipasi aktif dan untuk memenuhi kemungkinan kepercayaan atas inisiatif komunitas. Komunitas sendiri ada dua, yaitu rural community dan urban community. Pengembangan adalah proses meningkatkan pilihan, dalam arti pilihan baru, diversifikasi, berpikir tentang isu secara berbeda dan mengantisipasi perubahan.

Gagasan commuty development (perkembangan masyarakat) muncul dalam diskusi keilmuan sebagai sebuah respon terhadap banyaknya masalah yang dihadapi umat manusia pada akhir abad ke 20. Beberapa ahli menyatakan perkembangan masyarakat merupakan penjelmaan dari sebuah format politik baru pada awal abad ke 20. Perkembangan masyarakat mulai tumbuh sebagai gerkan sosial pada tahun 1970 menyusul kesadaaran progeresif dari sebagian komunitas internasional untuk memberikan perhatian terhadap kebutuhan layanan kesejahteraan bagi orang-orang lemah. Keberpihakan terhadap nasib orang-orang lemah dilakukan dengan mengubah model gerakan sosial dari kontrol sosial ke model praktik yang mencoba memberdayakan dan melibatkan mereka dalam proses perencanaan sosial dan pelaksanaan program-program kemasyarakatan secara kolaboratif-partisiopatoris.

Perkembangan masyarakat dalam konteks ini dilaksanakan dengan tujuan untuk mengembankan kemampuan masyarakat lapis bawah dalam mengidentifikasi kebutuhan, mendapatkan sumber daya dalam memenuhi kebutuhan, serta memberdayakan mereka secara bersama-sama.

Terminologi perkembangan masyarakat dalam perjalanannya merujuk pada sebuah sebuah pekerjaan profesional, metode pendekatan dalam pengembangan sosial dan ekonomi, komponen dalam kerja pelayanan kemanusiaan, pemikiran dan pendekatan intelektual terhadap dunia dan aktivitas politik. Pengembangan masyarakat dalam kerangka ini menjadi sebuah proses restruksisasi masyarakat dengan cara menawarkan pola-pola swadaya-partisipatif dalam mengelolah dan mengorganisasikan kehidupankehidupan sosial ekonomi sehingga akan lebih memungkinkan mereka memenuhi kebutuhannya sendiri dibandinkan waktu-waktu sebelumnya.

\section{Karakteristik/Sifat-sifat Kapitalisme}

Kapitalisme memiliki sejarah yang panjang, yaitu sejak ditemukan sistem perniagaaan yang dilakukan oleh pihak swasta. Di Eropa hal ini dikenal dengan sebutan guild sebagai cikal bakal kapitalisme. Tetapi, untuk saat ini kapitalisme tidak hanya di 
pandang sebagai suatu pandangan hidup yang menginginkan keuntugan belaka. Peleburan kapitalisme dengan sosialisme tanpa adanya pengubahan yang mendasar menjadikan kapitalisme tampak lebih lunak dari pada dua atau tiga abad yang lalu.

Sitem kapitalisme, kepemilikan atas sarana produksi umumnya bersifat formal absolut. Seseorang bisa saja tidak mengelolah atau sama sekali tidak terlibat dalam proses pengolahan lahan yang dimilikinya, meski dia secara sah diakui sebagai pemilik lahan tersebut. Di dalam kapitalisme satu-satunya jalan bagi semua orang untuk mendapatkan barang dan jasa yang telah dihasilkan yaitu pergi ke pasar dan menukarkan uang yang dimilikinya dengan barang tersebut. Begitu pula sebaliknya. Seseorang membutuhkan uang, maka ia akan harus pergi ke pasar dan membawa barang miliknya untuk di perdagangkan. Pasar adalah pranata pokok dalam kapitalisme yang memungkinkan proses pertukaran. Pasar adalah pranata yang menata jejaring sosial pertukaran berbasis penawaran dan permintaan. Simpul penghubung satu-satunya adalah dalam berhubungan utama pasar yaitu uang sebagai alat tukar. Sebagai sebuah sistem kapitalisme telah mengalami berbagai perubahan dan penyusuaian dengan tuntutan perkembangan zaman. Bentuk produksi kapitalisme. Yang paling awal yaitu yang disebutkaan Marx sebagai industri manufaktur, dimana sejumlah penrajin bekerja pada suatu perusahaan dengan spesialisasi dan pembagian kerja yang cukup rumit, namun efektif. Berbeda dengan sistem ekonomi tradisional yang acap kali inefisien, dalam kegiatan ekonomi kapitalis yang berkembang umumnya adalah kerja maksimal, dimana kerja buruh digantikan oleh mesin.

Kapitalisme adalah suatu paham yang menyakini bahwa kepemilikan modal bisa melakukan usahanya untuk meraih keuntungan sebesar-besarnya demi prinsip tersebut, maka pemerintah tidak dapat melakukan intervensi pasar guna keuntungan bersama. Walaupun demikian, kapitalisme tidak memiliki defenisi Universal yang tidak bias diterima secarah luas.

Ketika masyarakat berkembang menuju era post modernisme, kapitalisme umumnya juga makin berkembang tidak hanya makin menggurita masuk dan bergerak ke dalam berbagai jenis industri. Tetapi juga bergerak ke banyak negara menjadi perusahaan multinasional yang mengglobal. Seperti halnya pasar modern yang telah berkembang merupakan produk dari kapitalisme yang perkembangannya sangat pesat dan menjadi perusahaan multinasional yang mengglobal. 


\section{Modernisasi dan Globalisasi}

Istilah modern sering sekali dilawankan dengan istilah tradisional. Arti kata modernisasi dengan kata dasar "modern" berasal dari baahasa latin "modernus" yang berbentuk dari kata modo dan ernus. Modo berarti cara dan ernus menunjuk masa kini. Modernisasi berarti proses menuju masa kini atau proses menuju masyarakat modern. Modernisasi dapat pula berarti perubahan dari masyarakat tradisional ke masyarakat modern. Berbagai bentuk teknologi sebagai alat bantu aktivitas manusia pada masa itu yang kemudian diyakini sebagai lahirnya kapitalisme.

Ciri-ciri kemoderan yang lain dikemukakan oleh Kumar. Pertama, individualisme yaitu era modern individu memegang peranan sangat besar dalam sistem sosial. kedua, diferesensiasi yaitu terjadinya spesialisasi bidang kerja. Ketiga, rasionalitas atau perhitungan, yaitu adanya ciri efesiensi dan rasional setiap aspek kehidupan. keempat ekonomisme yaitu adanya dominasi aktivitas ekonomi, tujuan ekonomi, kreteria ekonomi, dan prestasi ekonomi. Globalisasi mempengaruhi dinamika kondisi perekonomian diberbagai level dari tingkatan global hingga lokal. Globalisasi diartikan sebagai proses yang menghasilkan dunia tunggal. Bagon Suryanto, Sosiologi Ekonomi Kapitalisme dan Konsumsi Di Era Masyarakat Post-Modernisme, hal:92.masyarakat seluruh dunia menjadi saling tergantung di semua aspek kehidupan, politik, ekonomi dan budaya. Globalisasi dapat diartikan sebagai penyebaran kebisaan-kebiasaaan yang mendunia, ekspansi hubungan yang melintasi benua, organisasi kehidupan sosial pada skala global, dan pertumbuhan sebuah kesadaran global bersama. Globalisasi telah menjadi tujuan utama pebisnis khususnya dengan kemunculan pasar-pasar global.

Globalisasi merupakan pandangan yang sangat modern yang menekankan kemampuan yang semakin meningkat di seluruh dunia dari organisasi-organisasi dan negara-negara modern yang bersifat kapitalistik untuk meningkatkan kekuasaan mereka dan menjangkau dunia. Globalisasi merupakan bagian khusus dari globalisasi. Ada dua teori yang menegaskan mengenai gejala tersebut. Pertama teori Marxian yang mengarahkan pandangan bahwa satu dari kekuatan-kekuatan pendorong utama di belakang globalisasi adalah kebutuhan perusahaan untuk memperlihatkan kemampuannya memperoleh keuntungan yang semakin meningkat melalui imperialisme yang semakin lama semakin menjauh dari jangkauan. Kekuatan pendorong adalah kebutuhan bagi perusahaan-perusahaan dan negara-negara dan insitusi-insitusi yang menopang mereka, 
untuk mendukung upaya-upaya mempertinggi kemampuan memperoleh keuntungan dengan cara meningkatkan hegemoni mereka. Kedua Teori Weberian yang menekankan ketersediaan yang semakin bertambah dari struktur-struktur yang dirasionalisasi dan kontrol mereka yang semakin meningkat atas orang-orang di seluruh dunia khususnya dalam bidang konsumsi.

Kapitalisme merupakan sebuah kekuatan besar yang muncul beriringan dengan globalisasi. Perusahaan-perusahaan kapitalis yang sangat kuat akan selalu berupaya untuk memperluas ekspansi pasar, bila tidak perusahaan-perusahaan lambat laun akan mengalami gulung tikar. Ekpansi pasar perusahaan besar tentu saja akan memasuki negara-negara yang dianggap potensial sebagai tempat untuk mengembankan modal. Gejala ini yang paling membawa implikasi paling besar akibat globalisasi. Perusahaanperusahaan asing akan digiring untuk mengeksplorasi dan kemungkinan kemungkinan untuk memperoleh keutungan pada wilayah-wilayah yang lebih terpencil dan relatif kurang berkembang. Gejala-gejala tersebut dapat dilihat dari berkembangnya pasar modern yang ada di Indonesia yang pada perkembangannya telah memasuki wilayahwilayah terpencil seperti di tempat peneliti pasar modern di Kamal Kabupaten Bangkalan.

Bagi kekuatan ekonomi yang kapitalistik, globalisasi ibaratkan adalah lahan atau habitat yang subur yang memungkinkan kapitalisme terus berekspansi merabah ke berbagai wilayah mencari cekuk-cekuk pangsa pasar baru yang terus terbuka. Bila zaman penjajahan kolonial, ekspansi kekuatan komersial diwujudkan dalam bentuk penjajahan dan ekpoloitasi habis-habisan terhadap sumber daya alam di negara jajahan. Maka di era globalisasi bentuk penjajahan yang dikembangkan kekuatan kapitalis umumnya lebih tampak sebagai ekspansi pangsa pasar dan promosi besar-besaran yang dikembangkan oleh kekuatan komersial untuk membentuk perilaku konsumen yang radikal dan terus berkesinambungan.

\section{Pasar Modern}

Negara pertama kali memperkenalkan pasar modern yaitu Amerika. Kemudian berkembangnya ke Eropa, Asia hingga ke seluruh penjuru dunia. Di Asia minimarket berkembang setelah perang dunia II. Negara yang memulainya Jepang, kemudian Korea, Taiwan, Hongkong, dan pada sekitar tahun 1970-an, pasar modern sampai ke Bangkok, Singapura, dan Indonesia mulai dari Jakarta hingga menyebar keseluruh penjuru tanah air. 
Pekembangan pasar modern tumbuh dalam berbagai model yang dibedakan atas luasnya, ragam, produknya, dan sistem transaksinya. bentuk bentuk pasar modern General Marchandising Store, Hypermarket, Departemen Store, Were House Store, dst. Pasar modern di Indonesia pada awalnya mengikuti gaya pasar modern Amerika dengan ciri-ciri rak barang gondola tinggi lebar, dengan lay out dan dekorasi sederhana. Mulai tahun 1980 trend pasar modern di Jakarta mulai mengikuti ke Jepang dengan ciri lay out dan dekorasi semarak banyak hiasan menarik dengan gondala. Industri ritel modern yang mengalami pertumbuhan cukup pesat di Indonesia saat ini adalah minimarket dengan konsep waralaba. Perkembangan pasar modern ini disebabkan banyak faktor, salah satunya perubahan pola konsumsi masyarakat saat ini yang bisa dikatakan pada tahap transisi, dari ritel tradisional ke ritel modern.

Perkembangan pasar modern berpotensi menimbulkan penyalah gunaan posisi dominan. Hal ini dapat memicu terjadinya praktek monopoli sehingga mengakibatkan persaingan tidak sehat antara pelaku usaha ritel, baik ritel modern maupun ritel tradisional. Kehadiran pasar modern yang menyasar konsumen menengah ke atas, saat itu lebih menjadi alternatif dari pasar tradisional yang identik dengan kondisi pasar yang kumuh, dengan tampilan dan kualitas yang buruk, serta harga jual rendah serta sistem tawar menawar konvensional. Namun sekarang ini kondisinya sudah banyak berubah. Persaingan yang terjadi saat ini tidak hanya antara pasar modern tetapi juga terhadap pasar tradisional. Perkembangan ekonomi saat ini memicu persaingan didalam negeri semakin bebas dan ketat sehingga diperlukan suatu strategi bersaing yang baik dan terpadu karena persaingan adalah kunci dari keberhasilan atau kegagalan suatu perusahaan. Kemampuan suatu perusahaan untuk dapat memenuhi kebutuhan konsumennya merupakan suatu tantangan yang harus dihadapi oleh setiap organisasi bisnis. Kebutuhan masyarakat yang makin meningkat berdampak pada persaingan antar perusahaan semakin meningkat tajam sehingga perusahaan harus mampu mendeteksi apa yang menjadi kebutuhan pasar atau keinginan konsumen serta membaca dan menterjemahkan setiap perubahan situasi sebagai peluang.

Tujuan strategi bersaing adalah menjadikan perusahaan pada posisi yang menguntungkan dan dapat dipertahankan terhadap kekuatan-kekuatan yang menentukan persaingan industri. Indonesia dengan jumlah penduduk ke-Empat terbanyak di dunia setelah Cina dan India memiliki potensi yang sangat besar bagi pasar modern pasar 
modern. Sejalan dengan perkembangan waktu dan perubahan gaya hidup masyarakat yang berpengaruh pada pola belanja, kegiatan bisnis retail atau bisnis eceran modern di Indonesia menunjukan perkembangan pesat.

\section{METODE PENELITIAN}

\section{Jenis Penelitian}

Jenis penelitian yang digunakan dalam penelitian ini adalah metode deskriptif kualitatif. Penelitian akan menggambarkan atau mendeskripsikan permasalahan dalam bentuk kata-kata bukan dalam bentuk angka. Penelitian deskriptif yaitu untuk membuat deskriptif atau gambaran secara sistematif, faktual dan akurat mengenai fakta-fakta, sifatsifat, serta hubungan antara fenomena yang diselidiki.

\section{Pendekatan Penelitian}

Dalam melakukan penelitian penulis menggunakan pendekatan sebagai berikut:

\section{Fenomenologi}

Fenomenologi adalah ilmu pengetahuan yang membahas tentang apa yang tampak mengenai suatu gejala-gejala atau fenomena yang pernah menjadi pengalaman manusia yang bisa dijadikan tolak ukur untuk mengadakan suatu penelitian kualitatif. Fenemenologi merupakan salah satu jenis penelitian kualitatif dimana peneliti melakukan pengumpulan data dengan observasi partisipan untuk mengetahui fenomena esensial.

Dalam penelitian ini penulis menggunakan pendekatan fenomenologi karena peneliti akan mengamati fenomena-fenomena yang terjadi di masyarakat untuk melihat persepsi masyarakat terhadap pasar modern di Kamal Kabupaten Bangkalan.

\section{Fungsional}

Menurut teori fungsional masyarakat merupakan suatu sistem sosial yang terdiri atas bagian-bagian atau elemen-elemen yang saling berkaitan satu sama lain dan saling menyatu dalam keseimbangan.

Dalam hal ini peneliti menggunakan pendekatan fungsional karena objek penelitian yaitu Pasar modern dan masyarakat memiliki hubungan yang menyatu satu sama 
lain dan terikat, serta terjadi hubungan timbal balik antara kedua objek penelitian tersebut untuk melihat persepsi masyarakat terhadap Pasar modern.

\section{Sumber Data dalam Penelitian}

Sumber data yang digunakan dalam penelitian yaitu:

- Data primer merupakan data yang diperoleh secara langsung dari lokasi penelitian setelah melakukan wawancara dan observasi terhadap objek-objek permasalahan yang akan diteliti.

- Data sekunder merupakan data yang terkumpul diperoleh dari studi kepustakaan (library research) laporan penelitian, buku-buku, literatul, serta sumber lain yang berkaitan dengan penelitian.

\section{Metode Pengumpukan data}

Metode pengumpulan data ialah teknik atau cara-cara yang dapat digunakan oleh peneliti untuk mengumpulkan data. Dalam pengumpulan data-data yang diperlukan untuk penelitian, maka diperlukan beberapa instrumen penelitian sebagai berikut:

a. Observasi

Kegiatan obeservasi meliputi melakukan pencatatan secara sistematik kejadiankejadian, perilaku, objek-objek, yang dilihat dan hal-hal lain yang diperlukan. Pada tahap awal observasi dilakukan secara umum, peneliti mengumpulkan data atau informasi sebanyak mungkin. Tahap selanjutnya peneliti harus melakukan obsevasi yang terfokus, yaitu mulai menyempitkan data atau iinformasi yang diperlukan sehingga peneliti dapat menemukan pola-pola perilaku dan hubungan yang terus menerus terjadi

b. Wawancara

Wawancara adalah tanya jawab dengan seseorang yang diperlukan untuk mengetahui informasi penting yang akan diteliti. Kajian dokumen merupakan sarana pembantu peneliti dalam mengumpulkan data atau informasi dengan cara membaca surat-surat, pengumuman, ikhtisar rapat, pernyataan tertulis kebijakan tertentu dan bahan-bahan tulisan lainnya.

E. Instrument Penelitian

Dalam melakukan penelitian penulis menggunakan instrumen sebagai berikut: 
a. Peneliti sebagai instrument (human instrument)

b. Buku catatan, camera. F. Metode Analisis Data

Setelah data terkumpul melalui prosedur pengumpulan data, maka langkahlangkah yang dilakukan oleh peneliti adalah menganalisa data. Dalam menganalisa data yang tersedia peneliti menggunakan langkah-langkah sebagai berikut:

1. Reduksi data, yaitu data yang diperoleh di tempat penelitian langsung dirinci secara sistematis setiap selesai mengumpulkan data, lalu laporan-laporan tersebut direduksi yaitu dengan memilih hal-hal pokok yang sesuai dengan fokus penelitian.

2. Penyajian data, yaitu penyajian kesimpulan informasi sistematis yang memberikan kemungkinan adanya penarikan kesimpulan dan pengambilan tindakan.

3. Penarikan kesimpulan, verifikasi data-data yang diperoleh.

\section{HASIL DAN PEMBAHASAN}

\section{Gambaran Lokasi Penelitian}

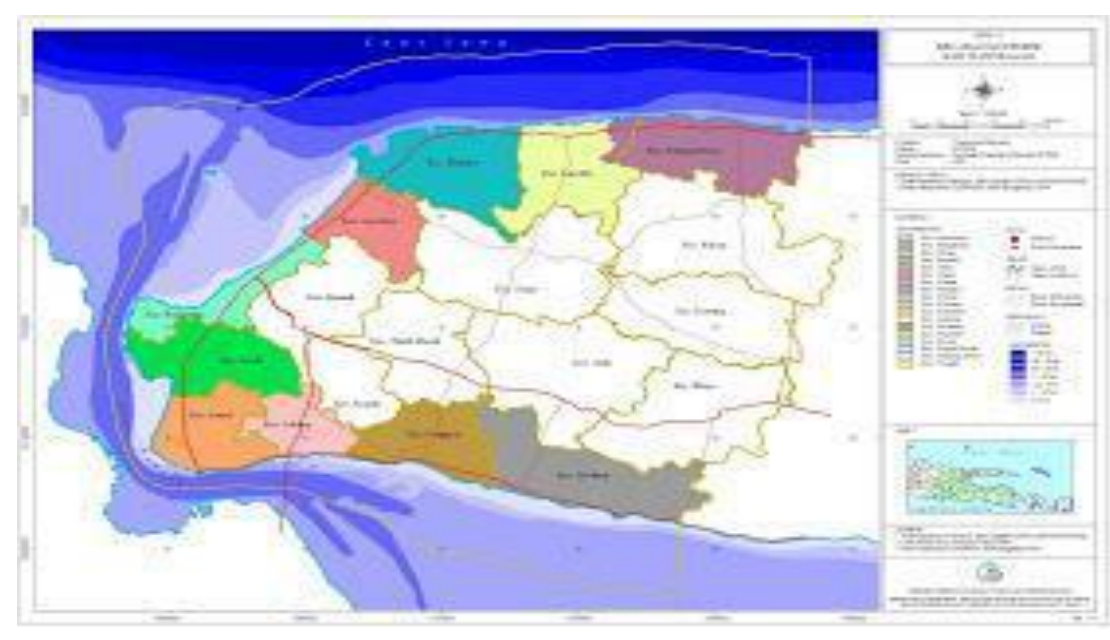

Gambar 1. Peta Kabupaten Bangkalan

Sumber: Badan Statistik Kecamatan Kamal Kabupaten Bangkalan.

Kabupaten bangkalan meliputi daerah pesisir dan pulau-pulau kecil yang terdiri dari 10(sepuluh) kecamatan, yaitu: Kecamatan Sepulu, Bangkalan, Socah, Modung, Kwanyar Arosbaya, Klampis, Tanjung Bumi, Dan Labang 


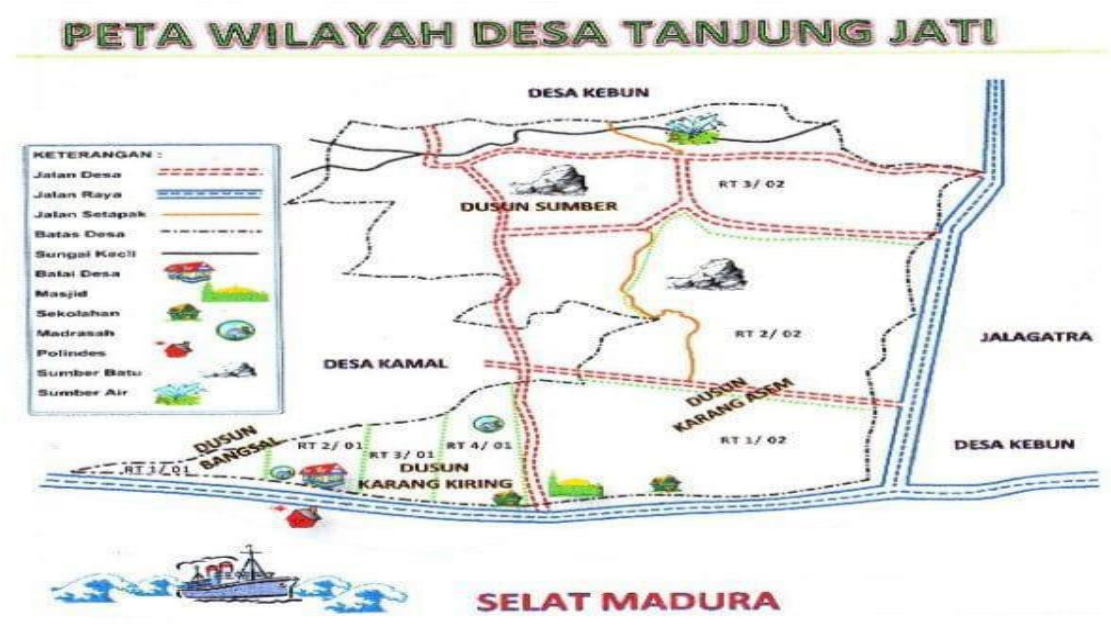

Gambar 2. Peta Kecamatan Kamal Kabupaten Bangkalan

Sumber: Badan Statistik Kecamatan Kamal Kabupaten Bangkalan.

\section{Pengaruh Pasar modern Terhadap Kehidupan Sosial Masyarakat Kamal}

Pasar merupakan produk kapitalisme perkembangan pasar modern dikarenakan globalisasi dan modernisasi telah berkembang. Kehadiran pasar modern menadakan bahwa perekonomian telah semakin maju. Pasar modern membawa perubahan sosial di tengah masyarakat. Pada saat dahulu masyarakat hanya berbelanja di pasar tradisional dan pedagang-pedagang baik pedagang kecil maupun besar sekarang banyak dari sebagian masyarakat yang berali ke pasar modern.

Pasar modern merupakan tempat berbelanja barang kebutuhan pokok di Indonesia pasar modern dapat kita temui hampir di seluruh wilayah Indonesia. Awalnya pasar modern hanya terdapat di wilayah perkotaaan. Akan tetapi, pada saat ini pasar modern sudah mengalami perkembangan pesat hingga ke pelosok pedesaan. Contoh yang peneliti teliti pasar modern yang terdapat di Kecamatan Kamal Kabupaten Bangkalan.

Keberadaan pasar modern di pasar Kamal telah menandakan kapitalisme telah memasuki daerah pedesaan. Dimana modal hanya dikuasai oleh satu pihak saja. Siapa yang kuat dan siapa yang besar ialah yang mengusai perekonomian. Seperti teori Karl Marx dimana ia menenggaskan bahwa emansipasi manusia hanya dapat dicapai dengan perjuangan antar kelas. Kelas sosial menurut Karl Marx merupakan gejala khas yang terdapat pada masyarakat pasca feodal. Marx kemudian menyebutkan di dalam struktur kelas ada perbedaan, yakni antar kelas borjois dan proletar. Dimana kaum borjois adalah para pemilik modal sedangkan proletar kaum kelas bawah. Jika kita kaitkan dengan teori 
Karl Marx borjois dapat kita liat pada pasar modern sedangkan proletar dapat kita liat pada pedagang kecil.

Keberadaan pasar modern telah mengubah corak perdagangan di Indonesia dimana pada awalnya pembeli dan penjual interaksinya sangat erat, mereka selalu bertutur sapa, tawar menawar, bahkan terbentuk hubungan keakrabatan antara penjual dan pembeli. Sifat individualisme sangat tinggi masyarakat yang datang di pasar modern berbelanja hanya datang saja mengambil barang tanpa bertanya-tanya dan tawar-menawar, lalu membayar kemudian pergi seperti yang diutarakan oleh Yanto selaku konsumen. Ia mengutarakan, keberadaan pasar modern sebenarnya ada dampak positif dan negatif, positif yaitu tempat yang bersih, tertata rapi, dan ada barang baru belum ada di pedagang-pedagang pasar tradisional ada di pasar modern. Sedangkan dampak negatifnya pedagang pasar tradisional sulit untuk bersaing pendapatan berkurang. Ia juga menabahkan kebanyakan pembeli hanya datang kemudian pergi tanpa berbicara panjang lebar, dan tawar menawar ia mengambil barang kemudian pergi.

Menurut peneliti kebanyakan masyarakat sekarang lebih didominasi ke pasar modern karena paradigma yang berkembang di masyarakat pasar modern lebih memberikan kesan yang nyaman ketika berbelanja di Pasar modern. Adanya produkproduk yang memberikan varian sehingga mereka tertarik berbelanja di Pasar modern dari pada pasar tradisional.

Yanto masyarakat Kamal, wawancara di depan pasar modern Kamal. Ia mengutarakan bahwa ia berjualan kurang lebih 10 tahun di Kamal sangat dirasakan perbedaan sebelum dan setelah adanya pasar modern. Kehadiran pasar modern sangat berpengaruh, serta membawah perubahan-perubahan baik dari segi ekonomi dan sosial. Ia menambahkan faktor yang menyebabkan ia sangat sulit untuk bersaing karena jarak dari pasar tradisional dekat dengan pasar modern.

Observasi penulis lihat di lapangan jarak pasar modern dekat dengan pasar tradisional dan pedagang-pedagang kecil. Pasar modern di Kamal terdapat bersebelahan dengan pasar tradisional, jaraknya sekitar $1 \mathrm{~km}$ antara pasar modern dan pasar tradisional. Pada kenyataannya, kita dapat menemukan pasar modern dekat dengan pasar tradisional, saat ini kita dapat menemukan pasar modern yang bersebelahan dengan kios ataupun pasar tradisional. Ditambah lagi dengan buruknya kondisi kios tradisional, kondisi ini haruslah mendapat penanganan yang serius dari pemerintah karena menyangkut hajat hidup orang 
banyak. Menjadikan pasar tradisional sebagai tempat perbelanjaan yang nyaman dan menarik adalah suatu tantangan untuk diupayakan.

Hal ini kurang efektif, jarak-jarak antara pasar modern yang satu dengan pasar tradisional yang lain cenderung berdekatan. Pemerintah bukan pihak yang memberikan izin berdiri. Akan tetapi, Dinas Tata Ruang yang memberikan izin berdiri. Pemerintah khususnya yang ada di Kecamatan Kamal hanya memperbolehkan, dan pasar modern mempunyai persatuan dan asosiasi. Tak dapat dipungkiri kehadiran pasar modern membuat kelesuan pedagang pasar tradisional hal tersebut terlihat banyak pedagang enceran dan demo. Menurut peneliti keberadaan pasar modern polemik sangat berpengaruh pada masyarakat adanya Pasar modern telah menadakan bahwa masyarakat desa telah maju dan terbuka akan hal baru. Pasar modern dapat memenuhi kebutuhan masyarakat untuk konsumsi barang-barang kebutuhan. Akan tetapi praktiknya salah karena melanggar dari aturan yang ditetapkan pemerintah. Oleh karena itu perlu pembaruan serta harus dicari jalan keluar atas permasalahan tersebut agar tidak terjadi masalah seperti yang terjadi di Pasar Kec. Kamal. Menurut analisis peneliti keberadaan pasar modern menadakan bahwa kapitalisme telah berkembang di masyarakat. Adanya pasar modern di depan pasar Kamal karena masyarakat yang memberikan tempat dan menyewakan tempatnya untuk uang merupakan bagian dari kapitalisme. Kebutuhan hidup yang tinggi, tuntutan ekonomi, dan kerasnya hidup karena segala sesuatu yang bernilai materi membuat seseorang mencari dan mengumpulkan modal sebanyak-banyaknya. Ia mengutarakan bahwa pemerintah mengalami kebimbangan dan kebingunan menghadapi permasalahan pasar modern sehingga membuat keputusan dan aturan bahwa Pasar modern diminta untuk dibuka pada pukul 10 pagi. Agar pedagang tradisional dapat diberikan kesempatan mengais rezekinya. Akan tetapi dari observasi yang penulis temukan peraturan tersebut tidak dipatuhi Pasar modern sudah buka Adanya kebutuhan hidup yang beraneka ragam, serta tuntutan hidup untuk memenuhi semua kebutuhan agar tercapai kesejahteraan sosial. membuat pasar modern dan pasar tradisional bersaing untuk perebutan konsumen. Pasar modern dan pedagang pasar tradisional mengumpulkan modal sebanyak-banyaknya. Hal tersebut merupakan bukti bahwa kapitalis telah mengusai roda perekonomian.

\section{Persepsi Masyarakat Terhadap Pasar modern di Pasar Kamal}


Persepsi merupakan pandangan seseorang terhadap sesuatu atau sebuah proses saat individu mengatur dan menginterepretasikan kesan-kesan sensorik mereka guna memberikan arti bagi lingkungan mereka. Persepsi lahir dari proses yang didahului oleh penginderaan yang merupakan stimulus yang diperoleh seseorang individu melalui alat penerimaan indra, kemudian stimulus itu diteruskan oleh syaraf ke otak kemudian akan memicu munculnya persepsi. Adapun persepsi terhadap Pasar modern seperti yang di ungkapkan oleh informan Andi Azhari. "Ia yang sering berbelanja di Pasar modern untuk meningkatkan prestise dimana sebagian orang berkata kebanyakan orang berduit yang berbelanja. Andi Pamma (56 tahun) salah satu masyarakat Kecamatan Kamal, Wawancara, pada tanggal7 Oktober 2018 di depan Pasar modern. "Supaya terkesan lebih diatas saya suka berbelanja di Pasar modern sangat berpengaruh terhadap kelas-kelas sosial dalam masyarakat seperti yang diutarakan informan diatas kebanyakan masyarakat kelas atas yang berbelanja di Pasar modern". Kelas menengah dan ke bawah lebih memilih untuk berbelanja di pasar tradisional. Adanya style dalam berbelanja agar dianggap kelas atas menimbulkan kesan bahwa Pasar modern merupakan wadah strafikasi sosial dalam masyarakat. Kehadiran Pasar modern juga disambut baik oleh masyarakat Kamal Kabupaten Bangkalan.

Ia mengutarakan kehadiran Pasar modern disambut baik karena pada dasarnya orang-orang akan lebih tertarik untuk berbelanja di Pasar modern. Adanya Pasar modern menambah wajah baru corak perdagangan terkhusus di Kamal. Interaksi antar ada beberapa tokoh besar yang bersebelahan dengan Pasar modern yang saling bertukar menukar informasi distributor barang murah. Akan tetapi pedagang kecil akan sulit untuk bersaing. Usahanya akan mengalami kemunduran.

Hubungan interaksi antara Pasar modern dan toko besar yang bersampingan dengan Pasar modern membawa persepsi positif. Kerja sama dalam hal distributor barang menunjukkan tidak ada kecemburuan sosial dan persaingan dalam perebutan konsumen dan masyarakat bersifat sehat. Persepsi terhadap Pasar modern dapat dilihat dari 2 aspek yaitu positif dan dan negatif. Aspek positif yaitu Pasar modern yang ada di Kamal telah menandakan ekonomi masyarakat telah berkembang pesat, mini market membawa perubahan besar pada masyarakat. Pasar modern telah menunjukkan masyarakat desa telah maju. Masyarakat desa yang awalnya terkenal primitive sekarang telah bergeser seiring dengan kemajuan teknologi, ilmu pengetahuan, konsumsi, modernisasi dan globalisasi, 
masyarakat mulai terbuka dan menerima hal baru. Keterbukaan masyarakat terhadap Pasar modern ditandai dengan mereka berbondong untuk masuk dan berbelanja di Pasar modern. Berikut ini tanggapan salah satu masyarakat di pasar Kamal.

Aspek negatif yaitu, persepsi masyarakat pedagang menganggap kehadiran Pasar modern membuat kelesuan pada pedagang kecil yang semakin terpuruk akibat adanya pasar moderen mereka sulit bersaing. Beberapa masyarakat yang berprofesi sebagai pedagang sempat mengeluh akan kehadiran Pasar modern karena mengurangi omsek mereka seperti yang diutarakan wahyuni.

\section{KESIMPULAN DAN SARAN}

\section{Kesimpulan}

Adapun kesimpulan dari penelitian yang berjudul "Menguak Kesenjangan Antara Pasar Modern dan Pasar Tradisional" yaitu adanya Pasar modern di pasar Kecamatan Kamal Kabupaten Bangkalan membawa pengaruh yang besar pada masyarakat desa yaitu terjadi perubahan sosial pada saat dahulu masyarakat hanya berbelanja di pasar tradisional namun sekarang telah beralih ke pasar moderen atau Pasar modern. Hal tersebut membuat masyarakat pedagang di pasar tradisional mengeluh karena mengalami penurunan omset.

Persepsi masyarakat terhadap Pasar modern terbagi menjadi 2 yaitu positif dan negatif. Apabila dilihat dari segi positif yaitu masyarakat sangat terbuka akan adanya Pasar modern hal itu menandakan bahwa masyarakat telah menerimah budaya baru, masyarakat telah moderen. Sedangkan dari segi negatif yaitu masyarakat pedagang yang omset berkurang akibat Pasar modern.

\section{Saran}

Adapun Saran dari penelitian artikel yang berjudul persepsi masyarakat terhadap pasar modern yaitu:

1. Penelitian ini diharapkan untuk Pemerintah sebagai pengayong masyarakat sebaiknya membantu masyarakat khususnya pedagang pasar tradional agar mampu bersaing di era globalisasi dan tidak tersingkir dalam perebutan konsumen.

2. Penelitian ini diharapkan untuk masyarakat agar dapat mengetahui dampak dan persepsi masyarakat terhadap mini market. 


\section{DAFTAR PUSTAKA}

Damsar. 2011. pengantar sosiologi ekonomi, Jakarta: Kharisma Putra Utama,

Faddilah, Ani Nur .2011. Dampak mini Market Terhadap Pasar Tradisional, Skripsi Instusi Agama Islam Negeri Wali Songo.

Prawironegoro, Darsono.2010.. Ekonomi Politik Globalisasi kajian kritis Kapitaliisme dan Perang Dunia ketiga, Jakarta: Nusantara consulting Hakim, Lukman. 2012. Prinsip-Prinsip Ekonomi Islam, Jakarta: Erlangga

Safitri, Ahmad Reza. 2010. Dampak Retail Modern Terhdap Kesejahteraan pedagang Pasar Tradisional Ciputat Tanggeran Selatan, Skripsi Universitas Islam Negeri Sarif Hidayatullah Jakarta 